Tarbawy : Jurnal Pendidikan Islam

ISSN : 2407-4462 (Cetak), 2614-5812 (Elektronik)

Vol. 8, No. 2, 2021, Hal. 38-45

DOI: https://doi.org/ doi.org/10.32923/tarbawy.v8i2.1920

\title{
Implementasi Pembelajaran Daring Sebagai Penguatan Pendidikan Karakter (Perspektif Psikologi Pendidikan Islam)
}

\author{
Hastik Oktavikanur Rahmawati ${ }^{1}$, Abdul Muhid ${ }^{2}$ \\ ${ }^{1}$ UIN Sunan Ampel Surabaya \\ ${ }^{2}$ UIN Sunan Ampel Surabaya
}

Info Artikel :

Diterima 3 Agustus 2021

Direvisi 21 Agustus, 2021

Dipublikasikan 21 oktober 2021

\section{Kata Kunci:}

Pembelajaran Daring

Psikologi Pendidikan Islam

\author{
Keywords: \\ Online Learning \\ Islamic Educational Psychology
}

\begin{abstract}
ABSTRAK
Kualitas mendasar dari kerangka instruksi pembelajaran daring adalah: interaksi tindakan terpadu dan program pendidikan yang terkoordinasi dalam pelaksanaannya, dengan teknik pertunjukan yang menarik, imajinatif, dan inventif dengan peningkatan. Metode yang digunakan peneliti adalah literature review (review jurnal). Hambatan, aturan, dan asumsi dalam memahami penggunaan kerangka kerja web Ini adalah topik yang menarik selama pandemi Coronavirus. Memang, bahkan dalam setiap kondisi dibatasi karena pandemi Coronavirus namun bagaimanapun juga dapat melakukan pembelajaran internet. Seluruh sekolah hari serta menargetkan membina sifat pengajaran Perhatian utama adalah bahwa Pembelajaran daring menunjuk sebagai salah satu upaya untuk membangun kepercayaan diri dan etika siswa dan menanamkan kualitas positif. Pembelajaran daring Ini adalah indikasi pembelajaran tanpa batas. Ini sangat berkaitan dengan Instruksi Islam bergantung pada Al-Qur'an dan Hadits terutama psikologi pendidikan islam.
\end{abstract}

\begin{abstract}
The fundamental qualities of the online learning instruction framework are: the interaction of integrated actions and educational programs coordinated in their implementation, with engaging, imaginative and inventive performance techniques with improvement. The method used by the researcher is a literature review (journal review). Barriers, rules and assumptions in understanding the use of web frameworks This is a topic of interest during the Coronavirus pandemic. Indeed, even in every condition is restricted due to the Coronavirus pandemic but nevertheless can do internet learning. Whole school day as well as targeting fostering the nature of teaching The main concern is that Online learning is pointed out as one of the efforts to build students'self-confidence and ethics and instill positive qualities. Online learning This is an indication of limitless learning. This is closely related to Islamic Instructions relying on the Qur'an and Hadith especially the psychology of Islamic education.
\end{abstract}

This is an open access article distributed under the Creative Commons Attribution License, which permits unrestricted use, distribution, and reproduction in any medium, provided the original work is properly cited. $\odot 2019$ by author.

\section{Koresponden: \\ Hastik Oktavikanur Rahmawati hastikrahma@gmail.com}

\section{Pendahuluan}

Sebuah pembelajaran adalah semua dampak yang dicapai tempat pembelajaran terhadap para siswa yang diberikan wali buat sekolah untuk dimiliki kapasitas dan membina kemampuan anak muda. pendidikan adalah pengerahan tenaga sadar yang dilakukan oleh otoritas publik melalui arahan, mendidik, atau persiapan yang mengakar dan kedapatan berada id luar sekolah ataupun idluar sekolah, untuk bersiaplah siswa buat memiliki pilihan untuk mengambil bagian dalam berbagai iklim di kemudian hari. Reaksi yang berbeda muncul mengenai pembicaraan program pemebelajaran daring sekolah yang diberangkatkan oleh Nadiem Makarim sebagai program pembelajaran tambahan untuk segala lini pendidikan yang ada saat ini.(Garmand, 2017:20)

Virus Corona mempengaruhi banyak pertemuan, kondisi ini telah menyusup dalam ranah pendidikan, pemerintah pusat hingga tingkat teritorial memberikan pendekatan kepada menutup setiap pendirian instruktif tunggal. Kejadian ini dikerjakan sebagai dorongan untuk mengatasi penyebaran virus Covid-19. Dipercaya bahwa semua organisasi instruktif tidak akan melakukan latihan Tentunya hal ini dapat membatasi penyebaran infeksi virus Corona. Kejadian ini sudah diberlakukan oleh berbagai negara 
yang dipengaruhi oleh infeksi Coronavirus ini.(Halal Syah, 2020:55-60) Strategi Lockdown atau Kebijan Isolasi dilakukan sebagai dorongan untuk mengurangi kerjasama dari banyak individu yang dapat memberikan izin masuk penyebaran Covid. Strategi yang diambil oleh berbagai negara termasuk Indonesia dengan menutup setiap tindakan instruktif, mendorong otoritas publik dan organisasi terkait untuk memperkenalkan siklus pembelajaran elektif untuk siswa dan siswa yang tidak dapat menyelesaikan interaksi instruksi dalam organisasi instruktif.(Dewi, Wahyu Aji Fatma, 2020:40) Kejadian semacam ini dikuatkan olehSurat Putaran Nomor 4 Tahun 2020 tentang Eksekusi Pendekatan Instruktif Di Masa Krisis Penyebaran Infeksi Covid (Coronavirus) dalam desain Portabel Desain Format (PDF) ini disahkan mentereri kebudayaan dan pendidikan pada tahun 2020 oleh Nadiem Makarim. Standar telah dilakuakn dalam pendekatan selama Corona virus yaitu "Kesejahteraan dan keamanan siswa, guru, staf pelatihan, keluarga dan jaringan" menjadi perhatian utama dalam pengaturan pengaturan pembelajaran. Sekolah Dasar adalah satu derajat pengajaran yang telah merasakan efek dari pandemi virus corona.(Balaji, 2012:22)

Pihak sekolah maupun sekolah sendiri mulai merubah metode pembelajaran yang bermula bersifat tatap muka menjadi perubahan ke pembelajaran non-vis-à-vis atau beberapa panggilan pembelajaran berbasis web dan Begitu pula pembelajaran online. Beraneka macam metode pembelajaran yang dapat dimanfaatkan oleh pendidik untuk menunjang pembelajaran peserta didik di rumah. Seperti yang ditunjukkan oleh Arsyad (2011) media pembelajaran internet atau Secara teratur disinggung sebagai elearning, itu adalah media untuk membantu sekolah dan bukan untuk alat merubah pelatihan. E-learning mempunyai interaksi sebagai media pembelajaran jarak jauh membuat pandangan dunia baru, lebih tepatnya tugas pendidik yaitu sebagai fasilitatir dan peserta didik sebagai "anggota dinamis" selama ini mencari tahu bagaimana untuk menginstruksikan.(Hernawan, Asep Herry, Hj Permasih, and Laksmi Dewi, 2012:82-90) Selanjutnya, pendidik dituntut untuk membuat prosedur pertunjukan yang bagus, menyajikan materi pertunjukan yang menarik, sementara siswa diperlukan untuk secara efektif mengambil minat dalam siklus pembelajaran. Pembelajaran internet juga sangat familiar dengan sebutan sebagai pembelajaran berbasis web. Pemanfaatan kerangka pembelajaran internet merupakan upaya yang harus dimungkinkan untuk menangani masalah dan memudahkan siswa untuk mempermudah mendapatkan materi pembelajaran. Riyanda (2020) mengklarifikasi bahwa sebagian bab harus dimungkinkan semasa pembelajaran di web (di web) berbicara satu sama lain dan berbicara tentang pembelajaran online.(Riyanda, A. R., Herlina, K., \&Wicaksono, B. A, 2020: 66-71)

Mengingat menurut psikologi eksprimental dianggap bahwa pengklarifikasian durasi untuk belajar atau berlatih dalam jangka waktu tertentu dicampur dengan waktu istirahat, akan membantu dalam mempercepat interaksi belajar dan perbaiki di memori.Buhibbin Syah, Psikologi dengan Pendekatan Terpadu (Jakarta: Rosdakarya, 2004), 154./ Alasan pengajaran pada dasarnya adalah untuk membangun kerangka karakter solid melalui penyamaran nilai dalam melatih, mengembangkan dan menanamkan pengetahuan yang antusias dan mendalam yang mewarnai latihan hidup mereka, mendorong dasar benarbenar mempertimbangkan kemampuan pelaksanaan memperoleh tugas, mengembangkan kecenderungan dan secara efektif mengambil bagian secara konsisten untuk mengeksploitasi terlebih lagi, mengisi waktu luang dengan belajar latihan aktivitas.

Muslim harus kembali ke jiwa yang suci yang mengakar Allah berfirman. Sejumlah besar perintahnya yang mendukung umat Islam tentang pentingnya hidup dalam sains. Misalnya, terkenal adalah permintaan untuk mencari informasi untuk setiap Muslim dan wanita Muslim dari snapshot snapshot dukungan ke kuburan. Demikian pula, Allah telah menjelaskan mengingatkan individu untuk mencoba untuk tidak meninggalkan usia yang lemah dalam kepercayaan, materi, kesejahteraan, hanya sebagai instruksi.(Marfiah Astuti, 2013:14) Seperti dalam firman Allah SWT dalam surat an-Nisaa' [4] ayat 9: "Dan" Bagaimana kalau kita takut kepada Allah orang-orang yang, jika mereka pergi? di belakang mereka adalah anak-anak lemah, yang mereka stres (bantuan pemerintah) mereka. Dengan cara ini, biarkan mereka takut kepada Allah juga, biarkan mereka berbicara tentang kenyataan." Urutan dalam Al-Qur'an harus memicu daerah setempat Muslim untuk bertindak dengan ukuran yang lebih luas dalam agama, khususnya dalam mengelola masalah instruktif. Artinya, sekolah harus ditenun sebagai bagian dari ibadah. Pendidikan sebagaimana ditunjukkan oleh Islam atau ajaran Islam, khususnya sekolah yang dirasakan dan diciptakan dari pelajaran utama dan kualitas yang terkandung dalam Sumber dasarnya adalah Al-Qur'an dan AsSunnah.(Ali, Moch, 2004: 18)

\section{Metode Penelitian}


Peneliti menggunakan metode literature review (review jurnal) khususnya dengan mengumpulkan beberapa artikel yang didapat melalui tampilan di Google Researcher, Microsoft Scholastic, Exploration Door dan Komunitas ilmiah Edu. Untuk mendapatkan artikel-artikel buku harian yang sesuai dengan topik tersebut, para analis menggunakan beberapa slogan inkuiri, khususnya orientasi seksual, pendidikan Islam, dan sekolah pengalaman hidup Islami. Terlebih lagi, dari beberapa referensi yang telah ditemukan, para ilmuwan memilih dan memutuskan mana yang cocok untuk dirasakan dan disurvei sepenuhnya dengan niat memiliki opsi untuk membantu pemikiran kritis dalam penyelidikan ini.(Marcus-Quinn, 2005:29)

\section{Pembahasan \\ Konsep Pembelajaran Daring}

WHO sejak Januari 2020 telah mengumumkan dunia menjadi krisis di seluruh dunia yang diidentifikasi dengan infeksi ini. Covid yang bergelut dengan system organ kita khususnya pernafasan kita dan itu terganggu sekali.covid-19 telah merajalela di berbagai dunia, begitupun yang dialami negeri kita tercinta yaitu Indonesia, maka program tetap berada di dalam rumah dilakukan sebagai dorongan untuk melumpuhkan Perpanjangan virus corona.(Darmadji, 2020:217-226) Agar sesuai dengan program otoritas publik, mode pembelajaran diubah menjadi ruang belajar virtual, sehingga siswa benar-benar mendapatkan hak mereka untuk memperoleh informasi namun tetap terlindungi di rumah tentu saja. Buana (2020) mengklarifikasi cara-cara yang telah ditempuh oleh otoritas publik untuk memiliki opsi untuk menangani kasus luar biasa ini, salah satunya adalah memajukan perkembangan sosial gerakan memisahkan. Ide ini mengungkapkan bahwa untuk mengurangi dan bahkan memutuskan rantai Kontaminasi virus corona, seseorang harus menghindari orang yang berbeda sepanjang 2 meter (Physical Distancing), dan tidak berhubungan langsung dengan orang lain, menjauhkan diri dari urusan sosial yang bersifat massal.(Dokumen Surat Edaran Nomor 4 Tahun 2020)

Disaat seperti ini membutuhkan guru, untuk situasi ini, pendidik untuk berkembang berevolusi dari dekat dan desain pembelajaran pribadi menjadi desain pembelajaran non-mata ke mata. Ada metode pendidikan yang lain sehingga dapat dimanfaatkan oleh pendidik untuk mekanisme menyampaikan informasi, khususnya pada pendidikan yang berbasis web dan dan pendidikan yang campuran atau sesuatu yang berkonsep (gabungan dari dua strategi pembelajaran, khususnya mata ke mata dan pembelajaran internet). Strategi pembelajaran internet tidak mengharapkan siswa tersedia di kelas. Pemain pengganti bisa mendapatkan pembelajaran melalui media web. (Naungkim, 2020:1-10) Hidayat mengklarifikasi bahwa Public Joint Dewan Ketidakmampuan Belajar (NJCLD) menetapkan "Hambatan untuk Peningkatan Pembelajaran" adalah istilah keseluruhan yang mengidentifikasi dengan batas-batas pertemuan heterogen, intngan, Pengaturan, dan keinginan: internet membiasakan pada saat corona virus oleh pendidik.(Hasan, 2006:22)

Di web atau pembelajaran elektronik online dan ada yang menyebutnya di web pembelajaran adalah gerakan belajar dengan menggunakana organisasi seperti (web, LAN, WAN) sebagai teknik untuk pengangkutan, kerja sama dan kantor dan didukung oleh berbagai jenis administrasi pembelajaran lainnya. Pembelajaran berbasis web sangat membantu untuk latihan pembelajaran di kelas (bimbingan wali kelas), khususnya sebagai: (1) Tambahan, sebagai tambahan jika Siswa memiliki kesempatan untuk memilah bagaimana cara menggunakan teori pendidikan berbasis web tidak, untuk situasi ini takada komitmen bagi peserta didik buat mendapatkan teori pendidikan berbasis web. (2) Tambahan, untuk suplemen jika teori pendidikan berbasis web disesuaikan untuk melengkapi bahan ajar yang diperoleh siswa di wali kelas. Materi pembelajaran berbasis web yang disesuaikan menjadi bahan tambahan atau obat bagi peserta didik dalam menhikutsertakan latihan pendidikan reguler. (3) Penggantian, sebagai pengganti jika materi pembelajaran berbasis web disesuaikan untuk menggantikan bahan ajar yang diperoleh peserta didik di dalam kelas.(Karwati, Euis, 2014:10-23)

Seperti yang ditunjukkan oleh Hanum pembelajaran berbasis web atau online adalah sebahai contoh jenis metode bekerja dengan pembelajaran dan dijunjung tinggi oleh pemanfaatan data dan inovasi korespondensi. E learning dapat dicirikan sebagai jenis inovasi data yang diterapkan di bidang sekolah sebagai dunia maya. Munir mengatakan bahwa istilah e-learning lebih tepat diharapkan sebagai upaya untuk melakukan perubahan pembelajaran di sekolah atau universitas menjadi bentuk struktur terkomputerisasi yang bersilangan inovasi web. Seok menyatakan bahwa "e-learning is another type of metode instruksional untuk pembelajaran di abad ke-21. E-educator adalah perancang pendidikan elearning, fasilitator asosiasi, dan spesialis topik". E-learning adalah kerangka kerja pembelajaran terbuka sourcece, framework pembelajaran yang memanfaatkan aplikasi web yang dapat dijalankan dan diakses 
dengan browser internet. (Karwati, Euis, 2014:10-23) E-learning adalah kerangka pelatihan yang memanfaatkan aplikasi elektronik untuk membantu pengajaran dan pembelajaran dengan media jaringan PC lainnya.

Warkintin dan Mulyadi, mengklarifikasi bahwa instruksi adalah kerangka kerja yang menumbuhkan misi yang benar-benar luas yang mengidentifikasi dengan peningkatan fisik, kemampuan, pikiran, sentimen, kapasitas, sosial hingga masalah kepercayaan atau keyakinan. sampai hambatan atau rintangan apa pun, pelatihan terus berjalan dengan baik. Kendala pada kegiatan ini adalah instruktur ditengah kondisi virus corona, pembelajaran dilakukan dengan sengaja di web dan tidak dapat dilakukan secara dekat dan pribadi di kelas. Kondisi ini mengharapkan instruktur untuk berkembang dalam siklus pembelajaran, khususnya pembelajaran internet (dalam jaringan). (Karwati, Euis, 2014:10-23) Pengaturan selama pandemi adalah untuk menemukan jawaban dengan memanfaatkan pembelajaran secara onlne. Pendidik diharuskan kreatif dalam memanfaatkan pembelajaran yang berbasis onlie ini. Hal ini sesuai dengan penilaian Tjandra, bahwa instruktur khususnya bekerja dengan perpustakaan kelas, modul, bacaan kursus, serta buku pendukung, dan khususnya akses web, seperti memberikan beberapa PC kepada siswa yang tidak membawa stasiun kerja. Jenis e-learning (pembelajaran berbasis elektronik) bagaimanapun akan tetap ada dan terus berkembang. Karena kepemilikan PC mengisi dengan cepat di planet ini, e-learning menjadi semakin meningkat berkembang dan efektif terbuka. Kecepatan asosiasi web berkembang, dan dengan itu, lebih banyak kebebasan untuk teknik persiapan penglihatan dan suara telah meningkat. Harapan dalam belajar dengan model online menjadi jawaban yang dapat membantu pembelajaran di pusat pandemi virus corona.(Balaji, 2012:22)

\section{Hambatan Pembelajaran Daring}

Yang menjadi penghalang atau penghalang utama adalah keadaan para wali murid yang lebih Manfaatkan aplikasi WhatsApps (WA) sebanyak-banyaknya. Hambatan berikutnya adalah kesulitan menemukan organisasi gadget web dan ponsel yang lebih sering disampaikan oleh wali yang bekerja. Website Whatsapp sangat efisien da mudah untuk anak karena anak-anak banyak yang dapat menggunakan Aplikasi tersebut. Penghalang selanjutnya adalah masalah koneksi. Mengingat konsekuensi dari pertemuan tambahan, dengan instruktur yang menggunakan pembelajaran dengan model online, menyatakan bahwa model online sepenuhnya sesuai untuk siswa. Menjelang dimulainya pembelajaran berbasis web, materi hanya diberikan melalui Microsoft Word Kemudian, kemudian siswa membaca, sehingga setelah beberapa saat siswa merasa lelah. Pada saat pendidik menyajikan pembelajaran berbasis web melalui video, siswa sangat antusias dalam mengikuti pembelajaran.(F Kochar, 2020:75) Terutama ketika melakukan pertanyaan latihan sebagai tes melalui Google Structures, siswa sangat bersemangat karena mereka bisa langsung melihat jawaban yang benar dan selanjutnya mereka juga dapat melihat skor langsung atau hasil dari pekerjaan mereka. Zoom Gathering terkadang diadakan karena tidak semua siswa mengingat bisa mendapatkannya terutama ada beberapa siswa yang memiliki masalah sinyal. (Imaniyati, 2018: 95)

Pembelajaran online dalam pelaksanaannya memiliki penghambat. Pencegah utama,ada juga dari beberapa siswa yang tidak memiliki (pribadi) handphone (HP) ataupun paketan data. Namun pencegah berikutnya adalah memiliki HP diwajibkan oleh kantor seluler dan asosiasi web, terhambat dalam menyampaikan tugas karena pesan yang merepotkan. Informasi lebih lanjut menjelaskan bahwa untuk siswa tertentu tidak memiliki ponsel sendiri, jadi harus mendapatkan. Kendala selanjutnya adalah bahwa wali memiliki ponsel namun wali bekerja sepanjang hari di luar rumah sehingga wali bisa pergi dengan sekitar waktu malam. Halangan yang keempat adalah kendala asosiasi web, beberapa siswa tidak memiliki ponsel dan organisasi web tidak dapat diterima. Kendala keempat, tidak semua anak memiliki kantor HP dan ada beberapa kelompok Orang-orang lanjut usia yang tidak pandai berinovasi.(Marcus-Quinn, 2013:33) Ini membuat penjaga sulit untuk pergi bersama dan bekerja dengan anak-anak. Kasus seperti ini sangat menekan dan instruktur perlu mengulangi hal yang sama peringatan. Kendala ke- 6 adalah bahwa data tidak selalu langsung didapat oleh penjaga gerbang dengan alasan bahwa kuantitas web terbatas. Misalnya hari ini ada tugas, tapi setelah 5 hari baru bisa buka WA Memang, bahkan pada awal pembelajaran berbasis web, siswa tidak dapat membuka catatan web WA karena mereka tidak tahu tentang aplikasi. Rintangan Ketujuh adalah sorotan HP terbatas, masalah dengan tanda dan standar web.(Marcus-Quinn, 2013:33)

Halangan prinsipnya terspesialisasi tidak semua pengawas mahasiswa memiliki kantor ponsel Android. Juga, banyak wawasan siswa keletihan dan keletihan belajar di web sehingga terkadang mereka menjawab pertanyaan dengan tidak hati-hati. Fokus dan inspirasi anak-anak belajar di rumah dan di sekolah 
tentu akan sangat unik. Berlawanan Kedelapan handphone yang digunakan untuk mengumpulkan tugas adalah handphone orang tuanya, jadi mahasiswa hanya bisa mengumpulkan tugas mereka setelah orang tua mereka pulang kerja. Bahkan ada beberapa anak yang tidak bisa menyelesaikan tugasnya. Foto-foto tugas yang dikirim dari WA juga kadang-kadang tidak memuaskan, sehingga sulit bagi instruktur untuk mengatasi. Hambatan ke-10 sedang dalam pemeriksaan kesungguhan mahasiswa dalam melakukan penilaian karena tidak bisa bertatap muka dengan pembimbing atau pembimbing pendamping. Selama belajar internet, ada beberapa hambatan, hambatan utama adalah ketika siswa merasa lelah, pendidik harus memikirkan sistem tentang cara terbaik untuk mengeluarkan anak-anak dari zona lelah mereka.(Kurnawanto, 2020: 41-49) Pendidik harus imajinatif dalam membuat pembelajaran internet yang menarik untuk mahasiswa. Hambatan berikutnya adalah terkadang penjaga mengeluh bahwa mereka tidak dapat mengklarifikasi secara mendalam kepada mahasiswa. Siswa kadang-kadang tidak patuh seperti yang diperintahkan oleh instruktur di sekolah. Siswa juga demikian, mereka lebih mudah ketika dijelaskan oleh guru. Penjaga sering tidak sabar untuk membantu. Hambatan ketiga adalah masalah tanda. Sekarang dan lagi ada beberapa siswa yang mengeluh bahwa mereka tidak memiliki pilihan untuk menyerahkan tugas karena masalah tanda. Penghalang keempat adalah dalam beberapa kasus bantuan orang tua hilang dengan alasan bahwa mereka harus bekerja dari pagi hingga sore.(Balaji, 2012:44)

Sampai waktu untuk membantu siswa dalam menangani tugas-tugas hanya sekitar waktu malam. Penghalangnya adalah jika siswa terlambat bereaksi terhadap tugas, sedangkan instruktur harus segera merekap skor. Halangan Yang pertama diidentifikasi dengan reaksi terhadap tugas yang diberikan adalah kesalahan waktu dalam bermacam-macam tugas. Siswa dapat mengirimkan tugas ketika wali ada di rumah. Halangan kedua, memeriksa kesungguhan siswa dalam melakukan penilaian. Hambatan ketiga, ketika memimpin obrolan video dengan cara zoom kadang-kadang diwajibkan oleh tanda yang tidak lancar. Percakapan melalui Ruang belajar Google kadang-kadang secara efektif mengambil bagian wali, bukan hanya siswa. empat penghalang, Tanda atau organisasi menjadi penghalang dalam berbagai usaha. Kendala kelima, tidak bisa menyaring mengukur secara langsung. Pendidik hanya dapat mengakui item. Hal ini menyebabkan zat Penemuan yang berfokus pada interaksi tidak dapat dilihat oleh instruktur. Item adalah satu-satunya hal yang dapat disaring oleh pendidik.(Hanayanda, 22017:195)

\section{Kelebihan Dalam Pembelajaran Daring}

Manfaat utama dari daring yaitu sangat leluasa. Berguna dengan alasan bahwa dapat membagikan tugas kapan pun dan melaporkan tugas kapan pun. selanjutnya, sangat bias beradaptasi dimanapun dan kapanpun. daring berbasis web meminta durasi panjang, mudah beradaptasi untuk penjaga gerbang yang tidak berada di rumah dan dapat mengubah kesempatan mereka untuk pergi dengan siswa untuk berpikir. Ketiga, menghemat waktu dan harus memungkinkan kapan saja. Semua siswa bisa mendapatkannya dengan sederhana, artinya cenderung dilakukan di mana saja. Penyampaian data lebih cepat dan dapat menjangkau banyak mahasiswa melalui WA Gathering. Keempat, itu lebih layak dan membuatnya lebih mudah untuk menerima penghargaan informasi, terutama saat menggunakan Google Structures. Jika Anda menggunakan Google Structure, nilainya bisa langsung dengan tujuan agar siswa lebih giat dalam melakukan usaha tersebut. Selain itu, siswa juga bekerja dengan dalam melakukannya.(MStrauser, 2010:76) Siswa cukup memilih keputusan tanggapan yang tepat yang dianggap benar dengan mengklik keputusan respon yang tepat yang dirujuk. Manfaat kelima adalah siswa dapat diperiksa dan bergabung dengan orang-orang satu sama lain. Manfaat keenam, pengajar dan siswa memperoleh pengalaman baru yang diidentifikasi dengan pembelajaran internet. Tugas wali dalam membantu siswa lebih banyak.(Fridani, 2019:20-29)

\section{Kelemahan Pembelajaran Daring}

Kekurangan daring ini yaitu tidak adanya inklusi peserta didik yang maksimal. Kontribusi mahasiswa yang dimaksud dapat dilihat dari konsekuensi inklusi mahasiswa setelahnya keuntungan berbasis web penuh dari awal mencari tahu bagaimana batas terjauh dari penddikan. Penelitian ini menunjukkan hasil sebagaimana berikut yaitu setengah dari peserta didik yang sepenuhnya termasuk, 33\% siswa yang3\% efektif disertakan. Sedangkan $17 \%$ lainnya, mahasiswa yang kurang dinamis dan kurang pembelajaran berbasis web.(Baker, 2008:45)

\section{Harapan Pembelajaran Daring Di Masa Pandemi Covid-19}

Asumsi bagi pendidik terhadap pembelajaran berbasis web adalah harapan utama, setelah kondisi pulih seperti biasa atau bahkan wabah virus corona selesai, sang pendidik percaya sebagai renungan belajar di wali kelas, pembelajaran berbasis web bagaimanapun dapat diselesaikan untuk melatih kemampuan 
pendidik dan mahasiswa pada periode abad 4.0. Harapan dari kedua pembelajaran ini adalah sebagai pilihan bagi pendidik dalam menerapkan model pembelajaran. Artinya membangun informasi dan menerapkan pemanfaatan yang tepat dari kemajuan inovatif. Harapan ketiga, ada perlakuan unik untuk siswa yang mengalami kendala dalam belajar. Harapan keempat(Baker, 2008:44), model pembelajaran internet Ini bagus untuk digunakan namun harus ditambah dengan model pembelajaran yang terputus. Masalah ini Karena, dalam hal ini pembelajaran berbasis web tunggal benar-benar pada saat itu keaslian dan kemandirian siswa dalam belajar. melakukan usaha liar. Sehingga dapat diterima jika model pembelajaran berbasis web ini diikuti dengan perluasan pembelajaran. Idealnya nanti ada modelnya berbasis web yang lebih baik mencari tahu bagaimana membantu mencari tahu bagaimana menjadi lebih kuat dan efektif umumnya disambut oleh mahasiswa. Harapan kelima adalah pembelajaran berbasis web dapat dimanfaatkan sebagai jawaban yang sangat bagus untuk membantu kemajuan belajar di rumah di masa pandemi seperti ini. Pekerjaan individu Wali di rumah diandalkan untuk sebanyak mungkin pergi bersama anak-anak dan gadis kecil mereka untuk belajar di rumah. Benda Hal positif yang dapat diperoleh adalah anak memiliki kedekatan individual dengan orang tuanya.(Hadisi, 2015:32)

\section{Implementasi Pembelajaran Dari Menurut Tinjauan Psikologi Pendidikan Islam}

Pembelajaran jarak jauh atau sering dikenal dengan pembelajaran daring (online) adalah model sekolah yang didanai negara yang bergabung Pendidikan Islam yang serius, khususnya dengan memberikan kesempatan yang luar biasa untuk mengembangkan agama siswa. Hal ini sesuai dengan permintaan pelajaran Islam. Ada banyak pengulangan Al-Qur'an dan hadits yang menyarankan untuk mencari informasi. Memang Bagian utama yang diwahyukan kepada Nabi Muhammad adalah Surah Al 'Alaq yang berbunyi: yang artinya: Seluruh sekolah hari adalah model sekolah yang didanai negara yang bergabung dalam kerangka Pendidikan Islam yang sungguh-sungguh, khususnya dengan memberikan kesempatan ekstra luar biasa kepada perluasan agama siswa.(Mohamed, 2015:45) Hal ini sesuai dengan permintaan pelajaran Islam. Ada banyak pengulangan Al-Qur'an dan hadits yang menyarankan untuk mencari informasi. Memang Bait utama yang diturunkan kepada Nabi Muhammad adalah Surah Al 'Alaq yang mengatakan: Artinya: "Bacalah dengan (menyebut) nama Tuhanmu Yang menjadikan" (QS. Al'Alaq: 1) Apalagi dalam hadits Nabi Muhammad SAW meminta untuk: kita untuk belajar tanpa batas di mana pun dan pada titik apa pun. Berikut hadits tentang mencari informasi: "Barangsiapa keluar mencari informasi, maka dia menghalang-halangi Allah sampai dia kembali". (HR. Turmudzi), "Mencari informasi dari ayunan sampai liang lahat" (H.R Muslim), Mencari informasi wajib bagi setiap muslim" (Riwayat Ibnu Majah, AlBaihaqi, Ibn Abdil Barr, dan Ibn Adi, dari Anas wadah Malik), siapa pun yang menempuh jalan untuk mencari informasi, Allah akan mudahkan baginya untuk masuk surga." (HR Muslim).(Gasong, 2018:333352)

Bagian dan hadits di atas adalah seruan dari Tuhan kepada manusia, semua jenis manusia, agar tidak duduk diam menyelesaikan sesuatu. yang tidak berharga. Sekolah sepanjang hari merupakan indikasi pembelajaran tanpa batas. Menyinggung bagian di atas bahwa di sepanjang hari siswa sistem pendidikan dihadapkan dengan dalam latihan belajar yang produktif sepanjang hari, sehingga Siswa tidak punya tenaga cadangan untuk melakukan latihan yang bersifat negatif apa lagi, kurang produktif. Pelaksanaan sistem pendidikan sepanjang hari memiliki tujuan mendasar untuk membingkai sifat moral siswa. Dengan demikian tujuan dari sistem pendidikan sepanjang hari tercapai, hal itu dilakukan pengarahan luar biasa yang ketat, antara lain dengan arahan petisi di sekolah. (Gasong, 2018:333-352)

Sistem pendidikan daring diterapkan secara luas di sekolah berbasis agama, yang menikmati manfaatnya sendiri, antara lain: Pertama, anak muda mendapat informasi umum harapan kemajuan ilmu pengetahuan. Kedua, anak-anak mendapatkan sekolah Islam yang sah dan relatif. Ketiga, anak-anak mendapatkan pendidikan karakter yang diharapkan peningkatan sosial-sosial yang dipisahkan oleh perkembangan data yang cepat dan globalisasi yang membutuhkan penghargaan saluran. Empat, kemampuan anak muda dialihkan melalui latihan ekstrakurikuler. Kelima, peningkatan minat, kemampuan, dan pengetahuan Anak-anak muda diperiksa sejak awal melalui proyek arahan dan bimbingan Kerangka kerja program sekolah sehari penuh adalah sebagai berikut:(Banaspati, 2018:66-76)

A. Membingkai perilaku Islam Sebuah. Perkembangan akhlak yang islami:

1. Informasi penting tentang Amanah, Islam, dan Ihsan

2. Informasi penting tentang etika yang sangat baik dan hina

3. Cinta kepada Allah dan Kurir-Nya

4. Kebanggaan dalam Islam dan ingin berjuang(Banaspati, 2018:66-76)

B. kecenderungan budaya Islam culture: 
1. Suka menghormati

2. Suka mempertimbangkan

3. Disiplin

4. Inovatif

5. Otonom

6. Kehidupan yang sempurna dan sehat

7. Perilaku Islami(Banaspati, 2018:66-76)

C. Dominasi informasi

1. Informasi tentang materi program instruktif yang penting

2. Mengetahui dan berbakat dalam cinta hari demi hari

3. Memahami secara lugas substansi amaliyah hari demi hari((Banaspati, 2018:66-76)

Untuk mengembangkan energi yang tersedia anak-anak menjadi lebih berharga, maka, pada saat itu sistem pendidikan sepanjang hari dilakukan dengan niat penuh untuk membentuk etika dan kepercayaan diri dalam menanamkan kualitas-kualitas positif, sama seperti memberikan pendirian yang kokoh dalam belajar di semua sudut.(Paul R, 2020:43-54)

Motivasi di balik instruksi adalah produk akhir yang diharapkan dari suatu kegiatan mengajar. Mengajar adalah demonstrasi yang disengaja untuk mencapai tujuan instruktif. Sementara tujuan dalam pengajaran adalah hal yang sangat mendesak, mengingat kenyataan bahwa Sekolah tanpa tujuan tidak disebut pelatihan. (Paul R, 2020:43-54) Sebuah eksplorasi mengatakan bahwa siswa akan mendapatkan banyak manfaat skolastik dan sosial dengan pembelajaran jarak jauh. Jangka waktu untuk merenungkan juga merupakan salah satu dari dari unsur-unsur pengalaman anak muda. pembelajaran jarak jauh serta penargetan menciptakan kualitas Sekolah utama adalah poin pembelajaran jarak jauh sebagai salah satu upaya pengembangan kepercayaan diri siswa dan etika dan menanamkan kualitas positif. pembelajaran jarak jauh adalah kerangka kerja pembelajaran yang selesai penuh, di mana latihan anak-anak sebagian besar dilakukan di sekolah daripada di rumah. Ide Premis pembelajaran jarak jauh adalah program pendidikan terkoordinasi dan tindakan terpadu yang adalah jenis penemuan yang diandalkan untuk menjebak anak muda (siswa) yang sangat cerdas yang dapat bergabung dengan bagian dari kemampuan dan informasi dengan disposisi yang besar. Premis instruktif melaksanakan pembelajaran jarak jauh setara dengan sekolah penting Islam. (Paul R, 2020:43-54)

\section{Kesimpulan}

Virus Corona mempengaruhi banyak pertemuan, kondisi ini telah menyusup dalam ranah pendidikan, pemerintah pusat hingga tingkat teritorial memberikan pendekatan kepada menutup setiap pendirian instruktif tunggal. Hal ini dilakukan sebagai dorongan untuk mencegah penyebaran penularan virus Corona. Mengingat menurut psikologi eksprimental dianggap bahwa pembagian waktu untuk belajar atau berlatih dalam jangka waktu tertentu dicampur dengan waktu istirahat, akan membantu dalam mempercepat interaksi belajar dan perbaiki di memori.

Sistem pendidikan daring diterapkan secara luas di sekolah berbasis agama, yang menikmati manfaatnya sendiri, antara lain: Pertama, anak muda mendapat informasi umum harapan kemajuan ilmu pengetahuan. Kedua, anak-anak mendapatkan sekolah Islam yang sah dan relatif. pengajaran Perhatian utama adalah bahwa Pembelajaran daring menunjuk sebagai salah satu upaya untuk membangun kepercayaan diri dan etika siswa dan menanamkan kualitas positif. Pembelajaran daring Ini adalah indikasi pembelajaran tanpa batas. Ini sangat berkaitan dengan Instruksi Islam bergantung pada Al-Qur'an dan Hadits terutama psikologi pendidikan islam.

\section{Referensi}


Aji, R. H. S. (2020). Dampak COVID-19 pada pendidikan di indonesia: Sekolah, keterampilan, dan proses pembelajaran. Salam: Jurnal Sosial dan Budaya Syar-i.(7), 5.

Ali, Moch,2004,Manajemen Pembelajaran, Disertasi UM Malang.

Banaspati,2018, Pengembangan pembelajaran berbasis blended learning pada mata pelajaran etomologi multimedia. JTP Jurnal Teknologi Pendidikan, 20(2):66-76.

Buhibbin Syah,2004, Psikologi Pendidikan dengan Pendekatan Terpadu, Jakarta: Rosdakarya.

Darmadji, 2020, Analisis kegiatan warga Indonesia Di masa (Covid-19) daniat Menjaga Kesejahteraan Jiwa. Salam: Jurnal Sosial dan Budaya Syar-i, 7(3):217-226.

Dewi, W. A. F. 2020. Dampak Covid-19 terhadap implementasi pembelajaran daring di Sekolah Dasar. Edukatif: Jurnal Ilmu Pendidikan, 2(1).

Dokumen Surat Edaran Nomor 4 Tahun 2020 tentang Pelaksanaan Kebijakan Pendidikan Dalam Masa Darurat Penyebaran Coronavirus Disease (Covid-19) dalam format PDF ini ditandatangai oleh Menteri Pendidikan dan Kebudayaan Nadiem Makarim pada tanggal 24 Maret 2020"

F Kochar,2020, Virtual Learning During the COVID-19 Pandemic. Journal of the American College of Cardiology.

Fridani,2019,Pengaruh ICT dan Minat Belajar terhadap Kesiapan Membaca Anak Usia Dini. Jurnal Obsesi : Jurnal Pendidikan Anak Usia Dini:20-29.

Garmand, 2017, Penerapan Sistem Pendidikan Jarak Jauh Dalam Lembaga Pendidikan Islam: Jurnal Pendidikan, Ta'allim. Vol. 28.No.2, 20.

Gasong, D. 2018. Belajar dan pembelajaran. Deepublish.

Hadisi, 2015, Implementasi Teknologi Informasi dalam Menciptakan Model Inovasi Pembelajaran (ELearning). Jurnal Al-Ta'dib, 8(1):31.

Hanayanda,2017, Menyusun Perencanaan Pembelajaran Melalui Pembinaan Kolaboratif Bagi Guru Kelas V di Dabin II Unit Pendidikan Kecamatan Gedangan. PEDAGOGIA: Jurnal Pendidikan, 6(2):195.

Hasan,2006 Model Alternatif Pembelajaran PAI, Jurnal Pendidikan Tadris. Vol.1 No.1:22.

Hernawan, A. H., Permasih, H., \& Dewi, L. 2012. Pengembangan Bahan Ajar. Direktorat UPI, Bandung, $4(11)$.

Karwati, E. 2014. Pengaruh Pembelajaran elektronik (e-learning) terhadap mutu belajar mahasiswa. Jurnal Penelitian Komunikasi, $17(1)$

Kurnawanto,2020, Sikap Guru terhadap Anak Usia Dini dengan Autism Spectrum Disorder. Jurnal Obsesi : Jurnal Pendidikan Anak Usia Dini: 41-49.

Maniyati,2018, Kesiapan Mengajar Guru dan Kesiapan Belajar Siswa sebagai Determinan Terhadap Hasil Belajar SISWA. Jurnal MANAJERIAL, 17(1): 95.

Marcus-Quinn, 2005, Metodologi Penelitian, Yogyakarta: Pustaka Pelajar.

Marfiah Astuti, 2013 , pengaplikasian Full Day School cara untuk Mendorong Perkembangan Sosial siswa TK Unggulan Al-Ya'lu Kota Malang”,Jurnal Kebijakan dan Pengembangan Pendidikan,Vo.1 No.2:14.

MStrauser,2010. Top Ten Tips for Student Teaching in Kindergarten. SRATE Journal, 19(2):76.

Naungkim, 2020, pengaplikasian Pembelajaran PAK di Abad 21. SIKIP: Jurnal PAK, 1(1):1-10.

Paul R, 2020, Pembelajaran pada masa pandemi COVID-19. Jurnal Teknologi Pendidikan, 22(1),2020:4354.

Riyanda, A. R., Herlina, K., \& Wicaksono, B. A, 2020 Evaluasi pengaplikasian Sistem online fakultas Ekononi Islam Universitas Lampung.: Jurnal Sosial dan Humaniora, 4(1): 66-71. 